\title{
АЛЕКСАНДР ЕФИМЕНКО
}

(iD) https://orcid.org/0000-0002-1922-7833

Ланьчжоуский университет (КНР)

Институт иностранных языков и литератур

Факультет русского языка

730000 Ланьчжоу

ул. Тяньшуйнаньлу, д. 222

efimenko200466@mail.ru

\section{АНАЛЕПСИС: «РЕТРОСПЕКЦИЯ" ИЛИ «ЭКСКУРС В ПРОШЛОЕ»?}

\author{
ANALEPSIS: "RETROSPECTION" \\ OR AN “EXCURSION INTO THE PAST"?
}

Анализируются мотивировки аналепсиса как одного из приемов построения сюжета. В русской филологической литературе данный прием именуется то вводимой воспоминаниями ретроспекцией, то обусловленным аукториальной активностью экскурсом в прошлое. Анализ повести Ю. Полякова Апофегей и привлекаемых попутно других произведений русской литературы показывает, что приемами мотивировки аналепсиса служат не только прием воспоминания, но и ряд других: ввод нового референта, стык информационных контекстов, анонсирующее сообщение. Поэтому наряду с терминами «ретроспекция» и «экскурс в прошлое» предлагается употреблять термины «доминантный аналепсис» и «недоминантный аналепсис». Подчеркивается, что в составе и доминантного, и недоминантного аналепсиса могут употребляться и приемы-ретроспекции, построенные на основе воспоминаний персонажа, и «эксурсы в прошлое», произведенные конструктивной активностью нарратора.

Ключевые слова: аналепсис, ретроспекция, экскурс в прошлое, прием воспоминания, приемы мотивировки аналепсиса, доминантный аналепсис, недоминантный аналепсис.

Possible motivations for analepsis as a plot-shaping device are analyzed in the paper. In the Russian scholarship this device is interpreted either as retrospection introduced by remembrances, or as an excursion into the past conditioned by auctorial activity. An analysis of Yuri Polyakov's novella Apofegei, supported by references to other Russian works, demonstrates that to motivate analepsis not only remembrance but also many other devices are used, such as introducing a new referent, anadiplosis of informative contexts, or an announced message. That is why the author of the paper proposes to use along with the terms retrospection and excursion into the past also the terms dominant analepsis and non-dominant analepsis. It is underlined 
that both the retrospection built on basis of a character's remembrances and excursions into the past produced by the narrator's constructing activity can be used within the frames of dominant and non-dominant analepses.

Keywords: analepsis, retrospection, excursion into the past, remembrance device, analepsis motivation devices, dominant analepsis, non-dominant analepsis.

Аналепсис ${ }^{1}$ - это прием объектной организации повествовательного текста ${ }^{2}$, заключающийся в нарушении хронологической последовательности изложения данных диегезиса, относящихся к «настоящему персонажей» ${ }^{3}$. В тексте, ведущемся из «настоящего нарратора» (или «настоящего наррации») и повествующего о «настоящем персонажей», в какой-то момент излагаются события из «прошедшего персонажей», т. е. в «исходный» текст вводится «производный» текст, в котором сообщаются более ранние, предшествующие «настоящему персонажей» элементы диегезиса, после чего сюжет, как правило, вновь возвращается в «настоящее персонажей».

В отечественной филологической литературе рассматриваемое явление именуется ретроспекцией. Этот термин появился в работах Н. С. Лейтес $^{4}$ и Н. Ф. Ржевской ${ }^{5}$ в целях теоретически и терминологически осмыслить увеличение двупланово построенных художественных произведений (поначалу только иностранных: Бильярд в половине десятого Генриха Белля, Расколотое небо Кристы Вольф и др.), включающих большое количество ретроспекций. Вскоре термин «ретроспеция» был институционализирован усилиями И. Р. Гальперина ${ }^{6}$, который включил ретроспекцию (наряду с проспекцией) в состав категорий художественного текста вместе с такими выявленными им текстовыми категориями, как информативность, цельность, когезия и др.

${ }^{1}$ Ж. Женетт, Повествовательный дискурс, [в:] он же, Фигуры: в 2 m., Москва: Издательство им. Сабашниковых 1998, т. 2, с. 75.

${ }^{2}$ В. И. Тюпа, Анализ художественного текста: учебное пособие для студентов филологических факультетов высших учебных заведений, 3-е изд., Москва: Издательский центр «Академия» 2009, с. 35.

${ }^{3}$ Ю. С. Маслов, Структура повествовательного текста и типология претериальных систем славянского глагола, [в:] он же, Избранные труды: Аспектология. Общее языкознание, Москва: Языки славянских культур 2004, с. 217.

${ }^{4}$ Н. С. Лейтес, О некоторых новых особенностях функции времени в композиции романа (На материле немеикой титературы), [в:] Сборник материалов к научной сессии вузов Уральского экономического района (февраль 1963). Филологические науки. Литературоведение, ред. Б. А. Базилевский, Свердловск 1963, с. 60-65.

${ }^{5}$ Н. Ф. Ржевская, Концепция художественного времени в современном романе (Функиия «ретроспекций» в романе), «Филологические науки» 1970, № 4, с. 28-40.

${ }^{6}$ И. Р. Гальперин, Текст как объект тингвистического исследования, 5-е изд., Москва: КомКнига 2007, с. 105-113. 
С давних пор значительное число исследователей, занимающихся анализом повествований с ретроспекцией (аналепсисом), полагает, что абсолютно преобладющим приемом, мотивирующим сюжетный ввод «прошедшего персонажей», является прием воспоминаний этого персонажа (акториальных воспоминаний). Так, Г. И. Рогова7 даже вводит соотносительные понятия «мотив воспоминаний» и «тема памяти», понимаемые как основа «ретроспективного повествования»:

В первой главе данного исследования [ее кандидатской диссертации - А. Е.] [...] выявляются социально-исторические и художественные предпосылки развития ретроспективного повествования. [...] Пристальное внимание сконцентрировано на анализе романа Л. Леонова Русский лес с точки зрения проблемы памяти и выявления художественных функций мотива воспоминаний, широко используемого писателем 8 .

Ей вторит Н. И. Бернадская: «Путем обращения к памяти, которая способна анализировать прошлое [...] достигается смещение разновременных событий» ${ }^{9}$. Из исследований последних лет приведем высказывание Г. А. Горбуновой, акцентируя внимание на начале цитаты: «Обычно выраженный воспоминанием, этот прием [ретроспекции - А. Е.] сообщает о “прошлой истории персонажей”, оценивает события, подбирает “ключи к пониманию персонажей или их мотивации”, усиливает драматичность текущего действия» ${ }^{10}$ (во внутренних кавычках - ее цитаты из работы М. Г. Меркуловой, исследовавшей ретроспекцию на драматургическом материале $\left.{ }^{11}\right)$.

В самом деле, воспоминание как сильный и удобный прием порождения аналепсиса употребляется достаточно часто. Сошлемся на пример из романа М. А. Булгакова Мастер и Маргарита, который содержит и ввод воспоминаний как мотивировки аналепсиса, и сами эти воспоминания. Одна из глав романа начинается со сцены пробуждения директора Театра

${ }^{7}$ Г. И. Рогова, Ретроспекиия как форма композиционных поисков в современной советской прозе. Автореферат диссертации на соискание ученой степени кандидата филологических наук, Москва 1983.

${ }^{8}$ Там же, с. 10.

${ }^{9}$ Н. И. Бернадская, Идейно-художественная функиия временных смещений в композиции современного романа. Автореферат диссертации на соискание ученой степени кандидата филологических наук, Киев 1986, с. 9.

${ }^{10}$ Г. А. Горбунова, Диалогичность и ретроспекиия как способы композиционного построения романа Я. Л. Вишневского "Одиночество в сети», [в:] Молодая наука: сборник научных трудов научно-практической конференции для студентов и молодых ученых, ред. Н. Г. Гончарова, Симферополь: ИТ «АРИАЛ» 2016, с. 332.

${ }^{11}$ М. Г. Меркулова, Ретроспекиия: шекспировская модель ретроспекиии в «Гамлете», «Филологические науки» 2006, № 5, с. 33-43, [электронный ресурс] http:// www.worldshake. $\mathrm{ru} / \mathrm{ru} /$ Encyclopaedia/3770.html [4.08.2019]. 
«Варьете» Степы Лиходеева, который неясно помнит события минувшего вечера и ночи: «...припоминалось только одно - что, кажется, вчера и неизвестно где он стоял с салфеткой в руке и пытался поцеловать какую-то даму... Дама от этого отказывалась...» ${ }^{12}$. Позже, после появления в его квартире Воланда, он припоминает всё яснее:

[...] стали выговариваться слова, и, главное, Степа кое-что припомнил. Именно, что дело вчера было на Сходне, на даче у автора скетчей Хустова, куда этот Хустов и возил Степу в таксомоторе. Припомнилось даже, как нанимали этот таксомотор у «Метрополя»... Да, да, да, это было на даче! ${ }^{13}$

Тем не менее более тщательная работа с текстами показывает, что мотивировка «прошедшего персонажей» вводом исключительно акториального воспоминания является далеко не единственным приемом порождения аналепсиса: его роль не следует абсолютизировать, как, впрочем, и преуменьшать. Ниже, на материале повести Ю. М. Полякова Апофегей, сюжет которой построен на основе сочетания «настоящего персонажей» и «прошедшего персонажей», мы покажем, какими именно мотивировками введены в ее сюжет аналептические сегменты.

Но сначала необходимо отметить, что, анализируя ретроспекцию, Рогова внесла важное уточнение в исходную концепцию. Она указала на различение двух схожих явлений в сюжете текста: это собственно ретроспекция и экскурсы в прошлое. Если ретроспекция - это такой «переход от настоящего к прошлому», который «представляет собой самосознание субъекта повествования» ${ }^{14}$, то

экскурс в прошлое представляет собой повествование, в котором переход от настоящего к прошлому осуществляется по воле автора, [...] это одна из разновидностей отступлений от главной темы, ввод, описание побочного или дополнительного по отношению к главной теме вопроса. Экскурсы в прошлое, в отличие от ретроспекций, - традиционная форма сообщения предыстории героя, свойственная классическим формам романа, это неизбежные звенья в эпическом повествовании ${ }^{15}$.

В предлагаемом далее анализе конкретного литературного материала мы намерены также оценить точность этих дефиниций.

${ }_{12}$ М. А. Булгаков, Мастер и Маргарита, [в:] он же, Собрание сочинений: в 10 m., Москва: Голос 1999, т. 9, с. 220.

13 Там же, с. 224.

${ }^{14}$ Г. И. Рогова, Ретроспекция как форма композиционных поисков..., с. 3.

${ }^{15}$ Там же. 
Перейдем к сюжетному анализу повести Полякова Апофегей. В ее сюжете вслед за каждым фабульным блоком эпизодов, данных в диалогических и недиалогических сценах и развертывающихся в «настоящем персонажей», несколько раз следует блок эпизодов, преимущественно в резюме, из «прошедшего персонажей», передающих информацию о Vorgeschichte (предыстории) этих персонажей. Такой прием, воспроизводимый трижды, структурирует классическую двуплановую сюжетную конструкцию: в «настоящем персонажей» представлено четыре сквозных фабульных блока A, B, C, D: A «Записка Нади Печерниковой»; В «Устная просьба Нади Печерниковой спасти больного сына»; C «Чистяков узнает, что сын Нади - это его сын»; D «Чистяков становится 1-м секретарем райкома»; в «прошедшем персонажей», или в аналепсисе, порождены три также сквозных фабульных блока A1, В1 и С1: A1 «Любовь Валеры и Нади»; В1 «Разрыв Валеры с Надей»; С1 «Валерий Павлович Чистяков - секретарь парткома института, а затем секретарь райкома по идеологии».

Рассмотрим, какими приемами осуществлен в сюжете переход от повествования в «настоящем персонажей» к аналепсису.

Диегезисом фабульного блока А является ряд следующих событий: открытие партийной конференции; получение секретарем райкома Валерием Павловичем Чистяковым записки от некоей Печерниковой; диалог о ней:

- Печерникова... Печерникова... - тужился вспомнить Мушковец. - По жилью она у меня не проходит. Кто такая?

- Понятия не имею, - спокойно ответил Валерий Павлович и положил записку в карман ${ }^{16}$.

Словно в ответ на это утверждение, после отбивки, графически знаменующей окончание блока А в «настоящем персонажей», следует информативное сообщение ${ }^{17}$ аукториального нарратора: «Двенадцать лет назад Надя Печерникова и Валера Чистяков чуть-чуть не поженились» (с. 15).

На уровне диегезиса это сообщение указывает на то, что Чистяков говорит Мушковцу заведомую неправду. Однако у этого сообщения есть и другие функции - на уровне сюжета.

${ }^{16}$ Ю. М. Поляков, Апофегей, Москва: Издательство АСТ: 2015, с. 14. Далее цитаты из повести даются по этому изданию с указанием страницы в скобках.

${ }_{17}$ Об информативном сообщении как о сюжетной мотивировке аналепсиса см. ниже, а также: А. Е. Ефименко, Аналептическое информативное сообщение как фактор текстопорождения, [в:] Русская словесность в научном, культурном и образовательном пространстве (к 90-летию со дня рождения профессора В. И. Максимова): материалы докладов и сообщений XXI международной научно-методической конференции, ред. Н. Т. Свидинская, СанктПетербург: ФГБОУВО «СПбГУПТД» 2016, с. 228-233. 
Во-первых, оно служит сюжетной мотивировкой для перехода от блока А в «настоящем персонажей» к аналептическому блоку A1 в «прошедшем персонажей». Основой для этого перехода выступает стык информационных контекстов, прежде всего, за счет повтора в них имен персонажей в концовке блока А и в зачине блока А1: Печерникова и Надя Печерникова, Валерий Павлович и Валера Чистяков. Различие в номинации персонажей вызвано различием их изменившихся социальных статусов в диегезисах блоков А и A1: Печерникова - это некая неизвестная просительница, Надя Печерникова - молодая красивая аспирантка; Валерий Павлович - могущественный секретарь райкома, Валера Чистяков - лишь молодой неопытный аспирант.

Прием стыка информационных контекстов как мотивировка ввода аналепсиса - отнюдь не открытие Полякова. Например, в рассказе А. Н. Толстого Гадюка такой же стык позволяет осуществить аналогичный переход от «настоящего персонажей» к «прошедшему персонажей». В абсолютном конце первой главы Гадюки в ответ на вопрос начальника отделения милиции: «- Ваше имя, фамилия, адрес?» звучит ответ: «- Ольга Вячеславовна Зотова...» ${ }^{18}$. И сразу начинается вторая глава, которая открывается информативным сообщением во внешней фокализации об убийстве десять лет назад купца Вячеслава Илларионовича Зотова и об обнаружении его полуживой дочери:

Десять лет тому назад в Казани загорелся среди бела дня на Проломной дом купца... Вячеслава Илларионовича Зотова. Пожарные обнаружили в первом этаже два трупа, связанные электрическими проводами: самого Зотова и его жены, и наверху - бесчувственное тело их дочери Ольги Вячеславовны, семнадцатилетней девицы, гимназистки ${ }^{19}$.

Хотя у Толстого в Гадюке имена-коннекторы обоих контекстов почти одни и те же - Ольга Вячеславовна Зотова и Ольга Вячеславовна, перед нами, несомненно, тот же прием стыка мотивов в двух сильных позициях глав, что и у Полякова в повести Апофегей.

Во-вторых, открывающее блок A1 информативное сообщение-анонс «Надя Печерникова и Валера Чистяков чуть-чуть не поженились» по своей экстенсиональной семантике является потенциально аналептическим. Оно задает определенную проспекцию развития событийного содержания диегезиса аналепсиса A1: персонажи, очевидно, любили друг друга, но любовь не привела их к браку.

${ }_{18}$ А. Н. Толстой, Гадюка, [в:] он же, Собрание сочинений: в 8 m., Москва: Правда 1972, т. 4 , с. 69 .

${ }^{19}$ Там же. 
Этот прием - еще более распространенный способ ввода аналепсиса («экскурса в прошлое»?). При этом аналепсис, введенный таким приемом, может быть очень разным по своему текстовому размеру: он может занимать и почти весь текст произведения, и лишь его составную часть, например, главу, и даже только часть главы.

Пример исходного сообщения, которое анонсирует диегезис почти всего текста произведения, - повесть Л. Н. Толстого Смерть Ивана Ильича. Ее вторая глава открывается анонсирующим сообщением аукториального нарратора: «Прошедшая история жизни Ивана Ильича была самая простая и обыкновенная и самая ужасная» ${ }^{20}$. Благодаря интенсиональной, интерпретирующей семантике эта анонсирующая фраза нарратора выступает в роли сюжетной мотивировки всей аналептической части повести. Данное нарраторское информативное сообщение-обобщение состоит из двух пропозиций: 1) жизнь Ивана Ильича была самая простая и обыкновенная и 2) жизнь Ивана Ильича была самая ужасная. Затем на протяжении всех аналептических глав, со второй по тринадцатую (финальную), эти две пропозиции разносторонне раскрываются и демонстрируются в эпизодах повествования ${ }^{21}$.

Примером анонса информативным сообщением не целого текста, а лишь одной его главы может служить повесть А. С. Грина Алые паруса. Ее вторая глава Артур Грэй начинается фразой: «Если Цезарь находил, что лучше быть первым в деревне, чем вторым в Риме, то Артур Грэй мог не завидовать Цезарю в отношении его мудрого желания. Он родился капитаном, хотел быть им и стал им $»^{22}$. Три сказуемых второго предложения-информативного сообщения содержат три соответствующие пропозиции: 1) Грэй родился капитаном; 2) Грэй решил быть им; 3) Грэй стал им. Они задают семантическое (или фабульное) развертывание трех частей диегезиса этой главы ${ }^{23}$.

Пример анонса только части главы - первое предложение главы девятой романа Булгакова Мастер и Маргарита: «Никанор Иванович Босой, председатель жилищного товарищества дома № 302-бис по Садовой улице в Москве, где проживал покойный Берлиоз, находился в страшнейших хлопотах, начиная с предыдущей ночи со среды на четверг» ${ }^{24}$.

20 Л. Н. Толстой, Смерть Ивана Ильича, [в:] он же, Полное собрание сочинений: 690 m., Москва: Художественная литература 1936, т. 26, с. 68.

${ }^{21}$ А. Е. Ефименко, «Смерть Ивана Ильича» Л. Н. Толстого: мотивировки порождения диегезиса, [в:] Интерпретация текста: лингвистический, литературоведческий и методический aсnекты: материалы XI Международной научной конференции, ред. Л. В. Бутыльская, Чита: ЗабГУ 2018, с. 36-39.

22 А. С. Грин, Алье паруса, [в:] он же, Собрание сочинений: 66 m., Москва: Правда 1980, т. 3, с. 19.

${ }^{23}$ А. Е. Ефименко, Аналептическое инбормативное сообщение.., с. 230-233.

${ }^{24}$ М. А. Булгаков, Мастер и Маргарита..., с. 238. 
Далее следует закономерное разъяснение этих хлопот: в резюме сообщается об опечатании квартиры Берлиоза и о последующем приходе к Никанору Ивановичу множества людей «с заявлениями, в которых содержались претензии на жилплощадь покойного» ${ }^{25}$. С момента, когда Никанор Иванович идет в «нехорошую квартиру», повествование возвращается в «настоящее персонажей» и разворачивается вновь в репродуктивном (изобразительном) регистре.

Вернемся к анализу аналептических мотивировок в сюжете Апофегея. В аспекте экстенсиональной семантики ситуация аналепсиса при переходе от блока А к блоку A1 наступает также благодаря вводу в диегезис нового для данного диегетического поля предмета. Этот предмет - записка Нади Печерниковой.

Прием ввода в диегезис некоторого предмета, выступающего как знак, заместитетель вводимого или уже введенного персонажа, также принадлежит к числу самых употребительных мотивировок аналепсиса. Достаточно вспомнить мотивировку портретом на могильном памятнике у И. А. Бунина в Легком дыхании:

На кладбище над свежей глиняной насыпью стоит новый крест из дуба...

$[\ldots]$

В... крест вделан довольно большой, выпуклый фарфоровый медальон, а в медальоне - фотографический портрет гимназистки с радостными, поразительно живыми глазами.

Это Оля Мещерская ${ }^{26}$.

Далее повествуется о событиях жизни и смерти Оли Мещерской ${ }^{27}$.

Другой пример предмета, служащего мотивировкой для аналепси$\mathrm{ca},-$ комсомольский билет в Тугом узле В. Ф. Тендрякова. Юный Саша разглядывает свой комсомольский билет, и этот референт выступает мотивировкой для ввода в диегезис аналептической сцены «прощания с комсомольским билетом», т. е. сцены партсобрания, прошедшего две недели назад с момента разглядывания, протекающего в «настоящем персонажей» ${ }^{28}$.

${ }^{25}$ Там же.

${ }^{26}$ И. А. Бунин, Легкое дыхание, [в:] он же, Собрание сочинений: в 6 m., Москва: Художественная литература 1988, т. 4, с. 94.

${ }^{27}$ А. Е. Ефименко, Нарративная композииия новелль И. А. Бунина «Легкое дыхание», [в:] Нарративные традици славянских литератур: Повествовательные формы средневековъя и нового времени, ред. Е. К. Ромодановская, И. В. Силантьев, Новосибирск: Новосибирский гос. ун-т 2009, с. 258-269.

${ }_{28}^{28}$ В. Ф. Тендряков, Тугой узел, [в:] он же, Избранные произведения: в 2 m., Москва: Гослитиздат 1963, т. 1, с. 145-376. 
Все эти предметы - записка, портрет, билет и многие другие - играют роль внешнего толчка для диегетической мотивировки рассказа о них.

Итак, стык информационных контекстов; анонсирующее информативное сообщение; ввод нового референта, - все эти разнородные приемы в комплексе служат мотивировками аналепсиса A1: большого, на много страниц, текстового блока в «прошедшем персонажей» о том, как именно персонажи Апофегея «чуть-чуть не поженились». Более того, каждого из этих приемов было бы достаточно для мотивировки аналепсиса. И лишь прием воспоминания, которому, как говорилось ранее, уделяют повышенное внимание многие исследователи ретроспекции, среди этих приемов не представлен.

Впрочем, надо сказать, что воспоминание как мотивировка аналепсиса все же будет позднее использоваться для порождения сюжета Anоøегея. Однако этот прием употреблен уже после ввода рассмотренного нами комплекса мотивировок аналепсиса A1. Дело в том, что ввод воспоминания как мотивировки аналепсиса потребовал перестройки повествовательной ситуации с аукториальной на акториальную.

Рассмотрим это подробнее.

Повествование в блоке А ведется всезнающим аукториальным нарратором, присутствие которого сигнализируется многочисленными метатекстовыми пометами: «К сведению» (с. 5), «Отметим» (с. 10), «Но об этом позже» (там же), (но также и значительно ниже, причем в аналепсисе В1: «Поясним»; c. 50). И аналептическое повествование A1, введенное комплексом трех вышеназванных аналептических приемов, идет, как в блоке А, поначалу в аукториальном дискурсе. Однако вскоре, благодаря фразе «До сих пор Чистяков отлично помнил первое появление Нади» (с. 16), содержащей временную и психологическую точки зрения персонажа [здесь и далее в статье курсив наш - А. Е.], повествование переводится в акториальное, которое ведется во «вспоминательном» режиме Чистякова. Периодически появляющаяся несобственно-прямая речь Чистякова, передающая его оценочное отношение давно прошедших итеративных событий на «картошке» и содержащая дейктическое теперь (теперь, как в предыдущем примере до сих пор, находится во временных координатах персонажа), еще больше усиливает эту акториальность:

Спать расходились обычно часа в два-три, а в семь уже вскакивали, умывались ледяной водой и, вибрируя от утреннего холода, расталкивали невменяемо-сонных студентов, которые втихаря тоже колобродили всю ночь. И ведь ничего: завтракали и, как выражалась Надя, бодренько отходили в поля, трудились, а вечером все начиналось сначала. А теперь вот поспишь вместо положенных восьми часов, скажем, шесть, и целый день скрипишь так, словно тебя палками отвалтузили (с. 37-38). 
Затем аналептический блок А1 прекращается и сюжет переходит к диегезису В «Просьба Нади Печерниковой спасти больного сына», возвращаясь в «настоящее персонажей». Лишь здесь нарратор ясно обозначает, что изложенные в «прошедшем персонажей» события мотивированы воспоминаниями героя:

«Ковалевский, конечно, тоже воздал бы должное докладчику, но сначала глянул в программу сверить имя-отчество, а этот на память шпарит, душегуб!» - подумал Чистяков, мгновенно возвращаясь из Надиной «хрущобы» в большой зал ДК (с. 47$)^{29}$.

Таким образом, воспоминание как мотивировка аналепсиса (очевидно, по Роговой, ретроспекции) использовано лишь во второй половине и в концовке блока А1 и при переходе к блоку В.

Еще раз подчеркнем, что рассматриваемая часть сюжета, формируемая блоками А и A1, порождается на основе трех одновременных приемов: собственно переход от А к аналепсису А1 мотивирован стыком контекстов и сценами с запиской, а событийный состав этого аналепсиса анонсирован во вводном информативном обобщающем сообщении, выступающем мотивировкой для своего последующего подробного разъяснения. Говоря еще шире, эта первая половина сюжета в целом развертывается благодаря конструктивной активности нарратора ${ }^{30}$, или, по Роговой, «проявлению авторской активности» ${ }^{31}$, ответственной, по ее мнению, за вводы «экскурсов в прошлое».

Однако в последующих частях текста повести специальные приемы порождения аналепсиса и выхода из него, подобные рассмотренным выше, уже не употребляются: переходы от блока В к блоку В1, а затем от С к С1 никак внешне не мотивированы. В частности, развертывание диегезисов аналепсисов В1 и С1 никакими начальными вводными сообщениями не обеспечивается. Здесь в силу вступает самодвижущаяся логика рассказываемой истории ${ }^{32}$. Историю, уже разделенную нарратором на два хронотопических плана «сейчас» и «тогда», надо далее просто дорассказать с соблюдением этого двупланового режима.

29 «Возвращаясь» здесь означает «мысленно возвращаясь», «возвращаясь в воспоминаниях".

${ }^{30}$ В. М. Маркович, «Архаические» конструкции в «Палате № 6», [электронный ресурс] https://www.academia.edu/37426139/ [4.08.2019].

${ }^{31}$ Г. И. Рогова, Ретроспекция как форма композиционных поисков..., с. 3.

32 А. Е. Ефименко, Логика саморазвития события и конструктивная активность нарратора, [в:] Актуальные вопросы филологии и методики преподавания иностранных языков: статьи и материалы Восьмой международной научно-практической конференции «Актуальные вопросы филологии и методики преподавания иностранных языков». 24-25 февраля 2016 2., ред. Т. Л. Масыч [и др.], Санкт-Петербург: РГГМУ 2016, с. 74-80. 
Для его поддержания движение диегезиса в обоих планах идет по строго хронологическому принципу: в фабульном блоке В изображены события, разворачивавшиеся во время первого перерыва в заседании, когда Чистяков узнает, что у Нади серьезно болен сын; в блоке C - события во время второго перерыва, когда выясняется, что этот мальчик - сын Чистякова; в блоке $\mathrm{D}$ - события во время конца заседания и в ходе вечера после него, когда Чистяков решается на отказ от партийной карьеры, чего, впрочем, не произойдет; в соответствующих им аналептических блоках В1 и С1 изложение диегезиса дается также в строго хронологическом порядке и разворачивается в форме то явных, то неявных воспоминаний Чистякова о пройденном им извилистом пути партийного функционера.

Однако в аспекте наррации и в блоке В1, и в блоке C1 фокализация повествования носит двойственный характер, проявляющийся порой на пространстве одной страницы. Так, с одной стороны, в блоках В1 и С1 сохраняется внутренняя фокализация Чистякова, вызванная ее «вспоминательной» мотивировкой, введенной, как мы показали, в ходе развертывания A1, т. е. интенсиональными усилиями «мысленного возвращения» персонажа из одного временного пласта в другой. В блоке В1:

Скажи тогда Валера эту длинную, продуманную фразу - и жизнь его пошла бы совсем по-другому: он никогда бы не стал секретарем райкома, он бы женился на Наде, и у их ребенка, в это Чистяков твердо верил, были бы самые здоровые почки.

Но тогда, одиннадиать лет назад, прежде чем раскрыть рот, Валера глянул на Семеренко, а тот, сурово нахмурившись, в упор смотрел на своего любимца и медленно шевелил губами, точно жевал что-то (с. 99);

в блоке $\mathrm{C} 1$ :

И еще одна неловкость, запомнившаяся с тех приймацких времен: Ляля [жена Чистякова - А. Е.] имела обыкновение любить в полный голос... [...] Чистяков умолял молодую жену быть посдержаннее, она обещала, крепилась, но внезапно забывалась... Постепенно Лялька сублимировала вопли в зубовный скрежет, да так и осталось. Сeгодня в их большой бездетной квартире, где при желании можно обораться, она в минуты довольно-таки редких объятий только громко скрипит зубами, отчего у Чистякова пробегает по спине озноб... (с. 138-139)

${ }^{33}$ Курсивом выделены лексемы и сочетания тогда, одиннадиать тет назад, запомнивщаяся с тех приймацких времен, сегодня, указывающие на двухронотопичность повествования, передаваемую в первом примере временной и психологической, а во втором - психологической и временной точками зрения Чистякова. 
С другой стороны, чуть ниже в том же массиве авторской речи и в B1, и в С1 звучит ироничный голос аукториального нарратора, который вновь, как в начальном блоке А, использует для самоманифестации приемы «старого письма», т. е. эксплицитную (или актуализованную) наррацию. В В1 это императив в обращении к читателю:

Таким образом, размолвка, случившаяся между ними в связи с вызовом Чистякова в партком, не была ни первой, ни последней. Валера даже привык к Надиной резкости и чем сильнее обижался на нее, тем больше вожделел. Согласитесь, в обладании умной и язвительной женщиной есть особая острота... (с. 78);

в С1 - авторское мы:

Николай Поликарпович [тесть Чистякова Кутепов - А. Е.] в течение многих лет покупал издательскую продукцию по специнформсписку, но читать ему, собственно, было и некогда, а для душевного отдыха у него, как мы уже знаем, имелся баян (с. 140) $)^{34}$.

Эта возвращенная в блоках В1 и С1 аукториальность позволяет вводить в текст несобственно-прямую речь не только Чистякова, но и его тестя (после двоеточия - несобственно-прямая речь Николая Поликарповича):

Между прочим, Николай Поликарпович был чрезвычайно доволен выбором своей дочери: страшно подумать, какого шалопая Лялька при своей доверчивости могла привести в дом! А Валера... Его не нужно было тащить за уши, доказывая, например, что нерасторопность - это не тупость, а привычка к обдуманности и обстоятельности, не нужно было вытаскивать из нехороших историй, объясняя, будто все они подстроены с исключительной целью - навредить ему, Кутепову... (с. 153).

Этот анализ фокализаций позволяет сделать вывод о том, что аналептическое повествование в блоках В1 и C1, передающее один и тот же компонент фабулы - Vorgeschichte, не привязано только к сознанию Чистякова, но может отражать также сознание аукториального нарратора и, следовательно, носит черты попеременно то «ретроспекции», то «экскурса в прошлое».

Обобщим наши наблюдения. Как было показано, аналепсис A1 мотивирован следующими приемами:

${ }^{34}$ Курсивом выделены признаки нулевой фокализации всезнающего нарратора, являющиеся одновременно проявлением его эксплицированности. 
- приемом стыка информационных контекстов;

- введением в абсолютное начало аналепсиса анонсирующего информативного сообщения, задающего экстенсиональную семантику развертываемого ниже аналептического фрагмента;

- введением в диегезис сцен с новым для данного диегетического поля предметом;

- приемом воспоминаний персонажа о прошлом, внешним (диегетическим) толчком к которым послужил этот предмет.

Употребление первых трех в блоке А1 и отказ от них в блоках В1 и С1 говорят о том, что в повествовании с аналепсисом наиболее уместный момент применения подобных средств приходится на начало развертывания диегезиса. Использование их в середине диегезиса и тем более в его конце избегается, поскольку образованная этими приемами хронотопическая двуплановость сюжета, установленная в первой половине повествования, далее поддерживается лишь вводимыми время от времени мотивировками, и этими мотивировками действительно являются воспоминания персонажа. Однако мы выяснили, что прием воспоминания не может считаться единственным способом мотивировки аналепсиса.

Между тем возникает вопрос: как квалифицировать первый в сюжете аналептический блок A1 - как «экскурс в прошлое» или как «ретроспекцию»? Введенный в сюжет по воле нарратора, он должен считаться «экскурсом в прошлое», в то время как аналогичные ему блоки В1 и С1 - это «ретроспекции», поскольку в их порождении участвует акториальный персонаж - носитель воспоминаний. При этом функционально блок А1 и блоки В1 и С1 играют роль «экскурсов». Они все являются означаемым для Vorgeschichte, «традиционной формы сообщения предыстории героя» ${ }^{35}$.

Выходом из замкнутого круга неустойчивых дефиниций в современной сюжетологии может быть использование категории аналепсиса, поскольку этот термин охватывает оба явления: и ретроспекцию, и экскурс в прошлое. Анализ показал, что различие между ними не зависит от того, как вводится аналептический сегмент - авторской активностью или воспоминаниями персонажа. Фактор различения «экскурса в прошлое» и «ретроспекции» следует искать не в субъектной, а в объектной организации текста: планом выражения какого компонента фабулы выступает этот сегмент.

Вот почему наряду с терминами «ретроспекция» и «экскурс в прошлое» мы предлагаем использовать термины «доминантный аналепсис» и «недоминантный аналепсис». При развертывании в аналептическом «прошедшем

${ }^{35}$ Г. И. Рогова, Ретроспекция как форма композиционных поисков..., с. 3. 
персонажей» всей завязочно-развязочной «пятичленки» ${ }^{36}$ событий излагаемой фабулы имеет место доминантный аналепсис, который в литературе встречается реже (повесть И. Тургенева Вешние водь, роман О. Форш Одеты камнем, рассказ А. Платонова Афродита). При развертывании в «прошедшем персонажей» лишь Vorgeschichte и свободных мотивов диегезиса (незавязочно-неразвязочных единиц фабулы) имеет место недоминантный аналепсис, который в литературе встречается чаще: от первой главы романа А. Пушкина Евгений Онегин до первой главы повести А. Куприна Олеся, а также в таких романах, как Двенадиать стульев И. Ильфа и Е. Петрова, Как закалялась сталь Н. Островского, Жизнь и судьба В. Гроссмана и многих других. При этом в составе и доминантного, и недоминантного аналепсиса могут использоваться и приемы-ретроспекции, построенные на основе воспоминаний персонажа, и «экскурсы в прошлое», произведенные конструктивной активностью нарратора.

Наша статья показала, что в повести Ю. Полякова Апофегей эпизоды в «настоящем персонажей» изображают основное действие фабулы и одновременно содержат разнообразные мотивировки для ввода эпизодов в «прошедшее персонажей», которые в свою очередь являются лишь планом выражения Vorgeschichte. Следовательно, нами было предложено описание сюжета с вторым типом аналепсиса - недоминантным аналепсисом.

Обнаружение и типологизация всех аналептических мотивировок, порождающих и доминантный, и недоминантный типы аналепсиса, - перспективное и многообещающее направление в изучении аналепсиса как одного из приемов построения сюжета.

\section{References}

Bernadskaya, Nina I. Ideino-khudozhestvennaya funktsiya vremennykh smeshchenii $v$ kompozitsii sovremennogo romana. Avtoreferat dissertatsiyi na soiskanie uchenoi stepieni kandidata filologicheskich nauk. Kiev, 1986.

Bulgakov, Mikhail A. Master i Margarita. In: Sobranie sochinenii: v 10 t. Vol. 9. Moskva: Golos, 1999: 156-522.

Bunin, Ivan A. Legkoe dykhanie. In: Sobranie sochinenii: v 6 t. Vol. 4. Moskva: Khudozhestvennaya literatura, 1988: 94-98.

Galperin, Igor R. Tekst kak obyekt lingvisticheskogo issledovaniya, 5-e izd. Moskva: KomKniga, 2007.

Gorbunova, Galina A. Dialogichnost i retrospektsiya kak sposoby kompozitsionnogo postroeniya romana Ya. L. Vishnevskogo "Odinochestvo $v$ seti». In: Molodaya nauka: sbornik nauchnykh trudov nauchno-prakticheskoi konferentsii dlya studentov i molodykh uchenykh, ed. N. G. Goncharova. Simferopol: IT «ARIAL», 2016: 332-333.

Grin, Aleksandr S. Alye parusa. In: Sobranie sochinenii: v 6 t. Vol. 3. Moskva: Pravda, 1980: 3-69.

${ }^{36}$ И. Н. Сухих, Теория литературы. Практическая поэтика: учебник, Санкт-Петербург: Филологический факультет СПбГУ 2014, с. 171. 
Leites, Natalya S. O nekotorykh novykh osobennostyakh funktsii vremeni $v$ kompozitsii romana (na materile nemetskoi literatury). In: Sbornik materialov $k$ nauchnoi sessii vuzov Uralskogo ekonomicheskogo raiona (fevral 1963). Filologicheskie nauki. Literaturovedenie, ed. B. A. Bazilevskii. Sverdlovsk, 1963: 60-65.

Markovich, Vladimir M. «Arkhaicheskie» konstruktsii v «Palate № 6»: http://lit.phil.spbu.ru/article.php?id=22

Maslov, Yurii S. Struktura povestvovatelnogo teksta i tipologiya preterialnykh sistem slavyanskogo glagola. In: Izbrannye trudy: Aspektologiya. Obshchee yazykoznanie. Moskva: Yazyki slavyanskikh kultur, 2004: 216-249.

Merkulova, Maiya G. Retrospektsiya: shekspirovskaya model retrospektsii v «Hamlete». http:// www.worldshake.ru/ru/Encyclopaedia/3770.html

Polyakov, Yurii M. Apofegei. Moskva: Izdatelstvo AST, 2015.

Rogova, Galina I. Retrospektsiya kak forma kompozitsionnykh poiskov v sovremennoi sovetskoi proze. Avtoreferat dissertatsii na soiskanie uchenoi stepieni kandidata filologicheskich nauk. Moskva, 1983.

Rzhevskaya, Nelli F. "Kontseptsiya khudozhestvennogo vremeni v sovremennom romane (funktsiya «retrospektsii» v romane)". Filologicheskie nauki. No. 4 (1970): 28-40.

Sukhikh, Igor N. Teoriya literatury. Prakticheskaya poetika: uchebnik. Sankt-Peterburg: Filologicheskii fakultet SPbGU, 2014.

Tendryakov, Vladimir F. Tugoi uzel. In: Izbrannye proizvedeniya: v 2 t. Vol. 1. Moskva: Goslitizdat, 1963: $145-376$.

Tolstoi, Aleksei N. Gadyuka. In: Sobranie sochinenii: v 8 t. Vol. 4. Moskva: Pravda, 1972: 65-104.

Tolstoi, Lev N. Smert Ivana Ilicha. In: Polnoe sobranie sochinenii: v 90 t. Vol. 26. Moskva: Khudozhestvennaya literatura, 1936: 61-113.

Tyupa, Valerii I. Analiz khudozhestvennogo teksta: uchebnoe posobie dlya studentov filologicheskikh fakultetov vysshikh uchebnykh zavedenii, 3-e izd. Moskva: Izdatelskii tsentr «Akademiya», 2009.

Yefimenko, Aleksandr E. Analepticheskoe informativnoe soobshchenie kak faktor tekstoporozhdeniya. In: Russkaya slovesnost $v$ nauchnom, kulturnom i obrazovatelnom prostranstve ( $k$ 90-letiyu so dnya rozhdeniya professora V. I. Maksimova): materialy dokladov i soobshchenii XXI mezhdunarodnoi nauchno-metodicheskoi konferentsii, ed. N. T. Svidinskaya. Sankt-Peterburg: FGBOUVO «SPbGUPTD», 2016: 228-233.

Yefimenko, Aleksandr E. Logika samorazvitiya sobytiya i konstruktivnaya aktivnost narratora. In: Aktualnye voprosy filologii i metodiki prepodavaniya inostrannykh yazykov: stati i materialy Vosmoi mezhdunarodnoi nauchno-prakticheskoi konferentsii «Aktualnye voprosy filologii i metodiki prepodavaniya inostrannykh yazykov». 24-25 fevralya 2016 g., ed. T. L. Masych. Sankt-Peterburg: RGGMU, 2016: 74-80.

Yefimenko, Aleksandr E. «Smert Ivana Ilicha» L. N. Tolstogo: motivirovki porozhdeniya diegezisa. In: Interpretatsiya teksta: lingvisticheskii, literaturovedcheskii i metodicheskii aspekty: materialy XI Mezhdunarodnoi nauchnoi konferentsii, ed. L. V. Butylskaya. Chita: ZabGU, 2018: 36-39. 